\title{
PERTANGGUNG JAWABAN DAN UPAYA PENANGGULANGAN TINDAK PIDANA PELAKU MEMPERDAGANGKAN MEREK PALSU
}

\author{
Jamillah*
}

Fakultas Hukum

Universitas Medan Area, Indonesia

Diterima Februari 2017; Disetujui April 2017; Dipublikasikan Juni 2017

\begin{abstract}
Abstrak
Undang-Undang No. 15 Tahun 2001 tentang Merek dan bentuk pertanggung jawaban bagi pelaku tindak pidana yang memperdagangkan merek palsu dapat dilihat dari segi hukum perdata dengan meminta ganti rugi, dan penghentian menggunakan merek. Dalam hukum pidana dapat berupa hukuman penjara sesuai dengan ketentuan yang berlaku dan juga denda serta dapat sanksi administrasi. Akan tetapi tindakan pemalsuan di bidang merek tetap dilakukan dan pada umumnya bertujuan untuk mendapatkan keuntungan. Seperti diketahui, bahwa kejahatan di bidang merek merupakan salah satu dari aktivitas kriminal yang berkembang cepat yang disebabkan karena adanya perkembangan di bidang teknologi dan informasi. Di sisi lain, berbagai upaya telah dilakukan untuk mengurangi terjadinya tindak pidana dibidang merek mulai dari dibentuknya Undang-Undang No. 15 Tahun 2001 tentang merek serta peningkatan kesadaran terhadap masyarakat untuk mau menggunakan produk asli. Namun kejahatan di bidang merek ini masihsaja terdapat di dalam masyarakat, bahkan dapat diperkirakan kasus kejahatan terhadap pemalsuan di bidang merek ini meski sudah ditangani, akan terus mengalami peningkatan. Oleh karena itu, bentuk pertanggungjawaban pidana pelaku tindak pidana yang memperdagangkan merek palsu, untuk upaya penanggulangannya agar dapat menimbulkan efek jera.
\end{abstract}

Kata Kunci: Hukum; Memperdagangkan; Merek Palsu

\begin{abstract}
In accordance with the Law no. 15 of 2001 on Trademarks and forms of liability for offenders who trade counterfeit trademarks can be seen in terms of civil law by seeking redress, and discontinuation using the mark. In criminal law can be a prison sentence in accordance with applicable provisions and also penalties and can be administrative sanctions. However, the act of counterfeiting in the field of brand remains done and in general aims to gain profit. As is known, that crime in the field of the brand is one of the fastgrowing criminal activity caused by the development in the field of technology and information. On the other hand, various efforts have been made to reduce the occurrence of criminal acts in the field of brands starting from the establishment of Law no. 15 of 2001 on the brand as well as increased awareness of the community to want to use the original product. But the crime in the field of this brand still exists within the community, and even predictable cases of crimes against fraud in the field of this brand, although already handled, will continue to increase. Therefore, the form of criminal liability of perpetrators of criminal acts that trade fake trademarks, in order to mitigate them in order to create a deterrent effect.
\end{abstract}

Keywords: Law; Trade; Fake Brand

How to Cite : Jamillah, (2017). Perbuatan, Bentuk Pertanggung Jawaban dan Upaya Penanggulangan Tindak Pidana Pelaku Memperdagangkan Merek Palsu 5 (1): 24-35
${ }^{*}$ Corresponding author:
P-ISSN-2549-9165
E-mail: jamillah3636@gmail.com
e-ISSN -2580-2011 


\section{PENDAHULUAN}

Seperti diketahui bersama bahwa manusia itu tidak mungkin hidup sendiri yang kemudian menjadi sekelompok manusia yang hidup dalam suatu tempat tertentu. Mereka yang berkelompok ini biasanya disebut dengan masyarakat, dimana dalam kehidupan masyarakat ini terdiri dari berbagai corak kepentingan, pertentangan serta hal-hal lainnya yang timbul diakibatkan oleh keberadaan masyarakat itu sendiri. Masyarakat kemudian berkembang dan lambat laun menjadi sesuatu yang komplek dalam kehidupannya yang semula sedemikian sederhana. Masyarakatpun kemudian memasuki dunia modern yang serba global pada perkembangannya.

Pada perkembangan perekonomian dunia yang berlangsung sangat cepat, arus globalisasi dan perdagangan bebas serta kemajuan teknologi, telekomunikasi dan informasi telah memperluas ruang gerak transaksi barang dan atau jasa yang ditawarkan dengan lebih bervariasi, baik barang dan jasa produksi dalam negeri maupun barang impor. Oleh karena itu, barang dan jasa produksi merupakan suatu hasil kemampuan dari kreativitas manusia yang dapat menimbulkan Hak Kekayaan Intelektual (HKI).

Hak Kekayaan Intelektual adalah kekayaan manusia yang tidak berwujud nyata tetapi berperan besar dalam memajukan peradaban umat manusia, sehingga perlindungan $\mathrm{HKI}$ diberikan oleh negara untuk merangsang minat para Pencipta, Penemu, Pendesain, dan Pemulia, agar mereka dapat lebih bersemangat dalam menghasilkan karya-karya intelektual yang baru demi kemajuan masyarakat. (lswi, 2010: 6)

Pada dasarnya HKI merupakan suatu hak yang timbul sebagai hasil kemampuan intelektual manusia dalam berbagai bidang yang menghasilkan suatu proses atau produk yang bermanfaat bagi umat manusia. Karya-karya di bidang ilmu pengetahuan, seni, sastra, ataupun invensi di bidang teknologi merupakan contoh karya cipta sebagai hasil kreativitas intelektual manusia, melalui cipta, rasa, dan karsanya. Karya cipta tersebut menimbulkan hak milik bagi pencipta atau penemunya. (Budi, 2009: 4).

Pengelompokkan HKl menurut Bambang Kesowo, menyatakan bahwa $\mathrm{HKI}$ pada intinya terdiri dari beberapa jenis yang secara tradisional dipilih dalam dua (2) kelompok, yaitu: Hak Cipta (Copyright), dan Hak atas Kekayaan Industri (industrial property) yang berisikan: Paten, Merek, Desain Produk Industri, Persaingan Tidak Sehat, Tata Letak Sirkuit Terpadu, Rahasia Dagang.

Dalam perkembangannya, HKI telah memiliki pengaturan di Indonesia adalah (Budi, 2009: 4) yaitu: 1) Merek diatur dalam UndangUndang Nomor 21 Tahun 1961 yang telah dicabut dengan Undang-Undang Nomor 19 Tahun 1992 jo. Undang-Undang Nomor 14 Tahun 1997. Tahun 2001 telah dikeluarkan Undang-Undang Nomor 15 Tahun 2001 tentang Merek yang mencabut ketentuan Undang-Undang Merek lama, 2) Paten diatur dalam Undang-Undang Nomor 6 Tahun 1989 diubah dengan Undang-Undang Nomor 13 Tahun 1997, kemudian dicabut dengan dikeluarkannya Undang-Undang Nomor 14 Tahun 2001 tentang Paten, 3) Hak Cipta diatur dalam Undang-Undang Nomor 6 Tahun 1982 sebagaimana diubah dengan Undang-Undang Nomor 7 Tahun 1987 dan diubah lagi dengan Undang-Undang Nomor 12 Tahun 1997, terakhir dicabut dengan Undang-Undang Nomor 19 Tahun 2002, 4) Persaingan Tidak Sehat, UndangUndang Nomor 5 Tahun 1999 tentang Larangan Praktek Monopoli dan Persaingan Tidak Sehat. 5) Desain Industri diatur dalam Undang-Undang Nomor 31 Tahun 2000. 6) Undisclosed Information/ Rahasia Dagang yang diatur dalam Undang-Undang Nomor 30 Tahun 2000. 7) Topography Right (Semi konduktor) (Tata Letak Sirkuit Terpadu) diatur dalam Undang-Undang Nomor 32 Tahun 2000.

Pada dasarnya, Hak Milik Intelektual merupakan suatu hak yang timbul sebagai hasil kemampuan intelektual manusia yang nantinya akan menghasilkan suatu proses atau produk karya yang bermanfaat. Karya-karya di bidang ilmu pengetahuan, seni, sastra, ataupun invensi di bidang teknologi merupakan contoh karya cipta sebagai hasil kreativitas intelektual manusia, melalui cipta, rasa, dan karsanya, sehingga karya cipta tersebut menimbulkan HKI bagi pencipta atau penemunya.

Latar belakang lahirnya Undang-Undang Merek antara lain didasari munculnya arus globalisasi di segenap aspek kehidupan umat manusia, khususnya dibidang perekonomian dan perdagangan. Perkembangan pesat di bidang teknologi informasi dan transportasi mendorong tumbuhnya integrasi pasar perekonomian dan perdagangan global. Kebutuhan, kemampuan dan 
kemajuan teknologi atas suatu produk sekarang ini merupakan pasar bagi produksi-produksi pengusaha pemilik merek dagang dan jasa. Semuanya ingin produk mereka memperoleh akses yang sebebas-bebasnya kepasar, oleh karena itu perkembangan di bidang perdagangan dan industri yang sedemikian pesatnya memerlukan peningkatan perlindungan terhadap teknologi yang digunakan dalam proses pembuatan, apabila kemudian produk tersebut beredar di pasar dengan menggunakan merek tertentu, maka kebutuhan untuk melindungi produk yang dipasarkan dari berbagai tindakan melawan hukum pada akhirnya merupakan kebutuhan untuk melindungi merek tersebut.

Hak-hak yang timbul dari hak kekayaan intelektual, khususnya hak atas merek suatu produk akan menjadi sangat penting yaitu dari segi perlindungan hukum, karenanya untuk mendirikan dan mengembangkan merek produk barang atau jasa dilakukan dengan susah payah, mengingat dibutuhkannya juga waktu yang lama dan biaya yang mahal untuk mempromosikan merek agar dikenal dan memperoleh tempat di pasaran. Salah satu cara untuk memperkuat sistem perdagangan yang sehat dalam mengembangkan merek dari suatu produk barang atau jasa, yaitu dengan melakukan perlindungan hukum terhadap pendaftaran merek.

Salah satu prinsip umum HKI adalah melindungi usaha intelektual yang bersifat kreatif berdasarkan pendaftaran. Secara umum, pendaftaran merupakan salah satu syarat kekayaan intelektual yang dihasilkan oleh seseorang. Beberapa jenis HKI yang mewajibkan seseorang untuk melakukan pendaftaran adalah Merek, Paten, Desain Industri, Desain Tata Letak Sirkuit Terpadu, dan Perlindungan Varietas tanaman. Sedangkan 2 (dua) cabang HKI lainnya yaitu Hak Cipta dan Rahasia Dagang tidak wajib untuk mendapatkan perlindungan. Hal ini sebagaimana yang termuat dalam Pasal 3 UndangUndang Nomor 15 Tahun 2001 tentang Merek, yaitu dengan melakukan pendaftaran hak atas merek. Dengan didaftarkannya merek, pemiliknya mendapat hak atas merek yang dilindungi oleh hukum.

Dalam Pasal 3 tersebut, dinyatakan bahwa hak atas merek adalah hak eksklusif yang diberikan oleh negara kepada pemilik merek yang terdaftar dalam Daftar Umum Merek untuk jangka waktu tertentu dengan menggunakan sendiri merek tersebut atau memberikan izin kepada pihak lain untuk menggunakannya.

Kemudian Pasal 4 Undang-Undang Nomor 15 Tahun 2001 Tentang Merek, menyatakan bahwa merek tidak dapat didaftar atas dasar permohonan yang diajukan oleh pemohon yang beritikad tidak baik. Dengan demikian, hak atas merek memberikan hak yang khusus kepada pemiliknya untuk menggunakan, atau memanfaatkan merek terdaftarnya untuk barang atau jasa tertentu dalam jangka waktu tertentu pula.

Perlindungan hukum diberikan sesuai dengan ketentuan-ketentuan yang diatur dalam Undang-Undang Nomor 15 Tahun 2001 Tentang Merek, yaitu sebagaimana yang termuat dalam Pasal 76 ayat (1) dan ayat (2) yang menyatakan bahwa pemberian hak kepada pemegang merek yang dilanggar haknya dapat melakukan gugatan kepada si pelanggar hak atas merek baik secara pidana maupun perdata.

Dari suatu produk barang dan jasa yang dibuat oleh seseorang atau badan hukum diberi suatu tanda tertentu, berfungsi sebagai pembeda dengan produk barang dan jasa lainnya yang sejenis. Tanda tertentu di sini merupakan tanda pengenal bagi produk barang dan jasa yang bersangkutan, yang lazimnya disebut dengan merek. Wujudnya dapat berupa suatu gambar, nama, kata, huruf-huruf, angka-angka, susunan warna atau kombinasi dari unsur-unsur tersebut. (Rachmadi, 2003: 320).

Pengertian Merek banyak macamnya. Beberapa diantaranya yang terpenting adalah (Utomo, 2010: 13): Merek adalah suatu tanda, yang dapat berupa: gambar, nama, kata, huruf-huruf, angka-angka, warna-warna, kombinasi warna, atau kombinasi dari diatas. (Budi, 2009: 26)

Merek adalah suatu tanda yang berupa gambar, nama, kata, huruf-huruf, angka-angka, susunan warna, atau kombinasi dari unsur-unsur tersebut yang memiliki daya pembeda dan digunakan dalam kegiatan perdagangan barang atau jasa. (lswi, 2010: 18)

Ruang lingkup Merek meliputi Merek Dagang dan Merek Jasa. Merek Dagang lebih mengarah pada produk perdagangan berupa barang, sedangkan Merek Jasa lebih terkait dengan produk perdagangan berupa jasa. Di samping, Merek Dagang dan Merek 
Jasa, juga dikenal adanya Merek Kolektif. Merek Kolektif dapat berasal dari suatu badan usaha tertentu yang memiliki produk perdagangan berupa barang dan jasa.

Para pemilik merek yang telah terdaftar akan mendapatkan Hak Merek, yaitu hak eksklusif yang diberikan oleh negara kepada pemilik merek yang terdaftar dalam Daftar Umum Merek. Berdasarkan Hak Merek tersebut, para pemilik Merek akan mendapatkan perlindungan hukum sehingga dapat mengembangkan usahanya dengan tenang tanpa takut Mereknya diklaim oleh pihak lain. Perlindungan terhadap hak atas merek bagi pemegang merek di Indonesia akhir-akhir ini masih sering dijumpai adanya pelanggaran terhadap hak atas merek tersebut.

Pelaksanaan perlindungan hak merek sangat dibutuhkan disebabkan perkembangan zaman yang sedemikian cepat. Hal ini dibuktikan dengan perubahan hak merek yang sedemikian cepat dari Undang-Undang Nomor 19 Tahun 1992 tentang merek, selanjutnya diubah dengan Undang-Undang Nomor 15 Tahun 1997 tentang perubahan Undang-Undang Nomor 19 Tahun 1992 tentang merek. Selanjutnya Undang-Undang Nomor 15 Tahun 1997 digantikan dengan UndangUndang Nomor 15 Tahun 2001. Perubahan yang sedemikan cepat menandakan bahwa dalam menyambut era globalisasi, maka pengaturan dan perlindungan merek menjadi amat penting.

Bahwa di dalam era perdagangan global sejalan dengan konvensi-konvensi internasional yang telah diratifikasi Indonesia peranan merek menjadi sangat penting terutama dalam menjaga persaingan usaha yang tidak sehat (Ok, 2010: 329). Dikatakan merek dapat mencegah terjadinya persaingan usaha yang tidak sehat dikarenakan dengan merek, produk barang atau jasa sejenis dapat dibedakan asal muasalnya, kualitasnya serta keterjaminan bahwa produk itu original. Kadangkala yang membuat harga suatu produk menjadi mahal bukan produknya, tetapi mereknya.

Merek itu sendiri hanya benda immaterial yang tidak dapat memberikan apapun secara fisik, benda materilnyalah yang dapat dinikmati. Ini yang membuktikan merek itu merupakan hak kekayaan immaterial. Undang-Undang Merek tidak menyebutkan bahwa merek merupakan salah satu wujud dari kekayaan intelektual. Sebuah karya yang didasarkan olah pikir manusia yang kemudian terjelma dalam bentuk benda immaterial.

Suatu hal yang perlu dipahami dalam setiap kali menempatkan hak merek dalam kerangka hak atas kekayaan intelektual adalah bahwa kelahiran hak atas merek diawali dari temuan-temuan dalam bidang hak atas kekayaan intelektual lainnya misalnya hak cipta. Pada merek ada unsur ciptaan, misalnya desain logo, atau desain huruf. Ada hak cipta dalam bidang seni. Oleh karena itu, dalam hak merek bukan hak cipta dalam bidang seni itu yang dilindungi, tetapi mereknya itu sendiri sebagai tanda pembeda. (Ok, 2010: 330).

Merek sebagai salah satu hak kekayaan intelektual mempunyai peranan yang sangat penting dalam kehidupan ekonomi, terutama dibidang perdagangan barang. Untuk membedakan suatu produk yang lain yang sejenis dalam satu kelompok kegiatan perdagangan itu sendiri sangat erat hubungannya dengan kegiatan produksi. Oleh karena pembahasan tentang perlindungan atas suatu jenis produk melalui mereknya menjadi suatu telaah yang sangat menarik.

Merek merupakan sesuatu yang ditempelkan atau dilekatkan pada suatu produk tertentu yang telah didaftarkan oleh pemiliknya melalui Direktorat Jenderal Hak Kekayaan Intelektual Departemen Kehakiman dan Hak Asasi Manusia Republik Indonesia dengan menjunjung tinggi itikad baik.

Suatu merek yang dikenal luas oleh masyarakat konsumen, dapat menimbulkan para kompetitor yang beritikad tidak baik untuk melakukan persaingan tidak sehat dengan cara mendaftarkan merek terdaftar secara tidak sah, peniruan, pembajakan, bahkan mungkin dengan cara pemalsuan produk bermerek dengan mendapatkan keuntungan dagang dalam waktu yang singkat. Tindakan oleh pihak yang beritikad tidak baik ini menurut Undang-Undang Nomor 15 Tahun 2001 adalah dilarang.

\section{PEMBAHASAN}

Merek sangat penting dalam dunia bisnis khususnya bidang periklanan dan pemasaran, karena publik sering mengaitkan suatu image tertentu, kualitas atau reputasi barang dan jasa dengan merek tertentu. Sebuah merek dapat menjadi pernyataan yang sangat berharga secara 
komersil. Merek suatu perusahaan sering kali lebih bernilai dibandingkan dengan aset rill perusahaan tersebut. (Jumroh, 2012: 33).

Dalam Pasal 1 Butir 1 Undang-Undang Nomor 15 Tentang Merek diberikan suatu defenisi tentang merek yaitu: tanda yang berupa gambar, nama, kata, huruf-huruf, angka-angka, susunan warna ata kombinasi dari unsur-unsur tersebut yang memiliki daya pembeda dan digunakan dalam kegiatan perdagangan barang atau jasa.

Era perdagangan global hanya dapat dipertahankan jika terdapat iklim persaingan usaha yang sehat. Di sini merek memegang peranan yang sangat penting yang memerlukan sistem pengaturan yang lebih memadai. Berdasarkan pertimbangan tersebut dan sejalan dengan perjanjian-perjanjian internasional yang telah diratifikasi Indonesia serta pengalaman melaksanakan administrasi merek, diperlukan penyempurnaan Undang-Undang Merek yang baru.

Berdasarkan perbedaan yang menonjol dalam undang-undang ini dibandingkan dengan undang-undang merek yang lama antara lain menyangkut proses penyelesaian permohonan. Dalam undang-undang ini pemeriksaan substantif dilakukan setelah permohonan dinyatakan memenuhi syarat secara admnistratif. Semula pemeriksaan substantif dilakukan setelah selesainya masa pengumuman tentang adanya permohonan, dengan perubahan ini dimaksudkan agar dapat lebih cepat diketahui apakah permohonan tersebut disetujui atau ditolak, dan memberi kesempatan kepada pihak lain mengajukan keberatan terhadap permohonan yang telah disetujui untuk didaftar.

Sekarang jangka waktu pengumuman dilaksanakan 3 bulan lebih singkat dibandingkan dengan jangka waktu pengumuman pada undangundang merek lama, dengan dipersingkatnya jangka waktu pengumuman, secara keseluruhan dipersingkat pula jangka waktu penyelesaian permohonan dalam rangka meningkatkan pelayanan kepada masyarakat. (Suryodiningrat, 1981: 337)

Selain perlindungan terhadap merek dagang dan merek jasa dalam undang-undang merek baru juga diatur perlindungan terhadap indikasi-geografis, yaitu tanda yang menunjukan daerah asal suatu barang karena faktor lingkungan geografis, termasuk faktor alam atau faktor manusia atau kombinasi dari kedua faktor tersebut, memberi ciri dan kualitas tertentu pada barang yang dihasilkan. Selanjutnya mengingat merek merupakan bagian dari kegiatan perekonomian/dunia usaha, penyelesaian sengketa merek memerlukan badan peradilan khusus, yaitu Pengadilan Niaga sehingga diharapkan diharapkan sengketa merek dapat diselesaikan dalam waktu yang relatif cepat. Sejalan dengan itu, harus pula diatur hukum acara khusus untuk menyelesaikan masalah sengketa merek seperti juga bidang hak kekayaan intelektual lainnya.

Pengaturan internasioanl yang menyangkut tentang merek adalah traktat pendaftaran merek dagang (TRT) tahun 1973. Traktat ini telah dibuat selama kenferensi WIPO (organisasi HKI di dunia) yaitu perjanjian-perjanjian internasional yang bersifat mendasar yang mengenai hak kekayaan intelektual yang di adakan di Wina pada tanggal 12 juni 1973, (Lindsey, 2000: 26) yang mana traktat merek dagang ini memungkinkan diperolehnya pendaftaran internasional dengan satu permohonan saja. Pendaftaran TRT tersebut tidak tergantung pada pendaftaran sebelumnya di negara asalnya. Selanjutnya Konvensi Nice merupakan juga perjanjian internasional di bawah naungan WIPO untuk penggolongan barang dan jasa secara internasional tahun 1957 kemudian diubah di Stocholm (1967) dan Jenewa (1977). Dengan konvensi ini telah dianut penggolongan barang dan jasa secara internasional yang berlaku terhadap seluruh negara anggota yang telah mengadakan perjanjian nice dan juga menurut Konvensi Paris tahun 1883.

Merek sebelum Undang-Undang No.15 Tahun 2001 telah mengalami tiga (3) kali perubahan, yang pertama diatur di dalam Undang-Undang Merek No. 21 Tahun 1961, yang kedua diatur di dalam Undang-Undang Merek No. 19 Tahun 1992, dan yang ketiga diatur dalam Undang-Undang Merek No.14 tahun 1997.

Dalam hal ini oleh karena perkembangan zaman maka No. 21 Tahun 1961dinyatakan dan dinilai sudah tidaksesuai lagi dengan perkembangan keadaan dan kebutuhan. Alasan lainnya juga dapat dilihat di dalam Penjelasan Undang-Undang Merek No. 19 Tahun 1992 yang antara lain mengatakan (Ok, 2010: 332):

Materi Undang-Undang No. 21 Tahun 1961 bertolak dari konsepsi merek yang tumbuh pada masa sekitar Perang Dunia II. Sebagai akibat 
perkembangan keadaan dan kebutuhan serta semakin majunya norma dan tatanan niaga, menjadikan konsepsi merek yang tertuang dalam Undang-Undang No. 21 Tahun 1961 jauh tertinggal. Hal ini semakin terasa pada saat komunikasi semakin maju dan pola perdagangan antarbangsa sudah tidak lagi terikat pada batasbatas Negara. Keadaan ini menimbulkan saling ketergantungan antar bangsa baikdalam kebutuhan, kemampuan maupun kemajuan teknologi dan lain-lainnya yang mendorong pertumbuhan dunia sebagai pasar bagi produkproduk merdeka.

Perkembangan norma dan tatanan niaga itu sendiri telah menimbulkan persoalan baru yang memerlukan antisipasi yang harus diatur dalam ini. Di dalam Undang-Undang Merek No.19 Tahun 1992 perbuatan-perbuatan yang dilarang dalamruang lingkup merek itu ada diatur di dalam Pasal 81-Pasal 86 Merek No. 19Tahun 1992.

Adapun perbuatan-perbuatan yang dilarang itu dalam ruang lingkup tindak pidana merek antara lain:

Tiap perbuatan yang dilakukan oleh siapa pun juga dalam hal ini menggunakan merek yang sama pada keseluruhannya dengan merek terdaftar milik orang lain atau badan lain untuk barang atau jasa sejenis yang diproduksi dan atau diperdagangkan.

Tiap perbuatan yang dilakukan oleh siapa pun juga dalam hal ini dengan sengaja dan tanpa hak menggunakan merek yang sama pada pokoknya dengan merek terdaftar milik orang lain atau badan lain, untuk barang atau jasa sejenis yang diproduksi dan atau diperdagangkan.

Tiap perbuatan yang dilakukan oleh siapa pun juga dalam hal ini memperdagangkan barang atau jasa yang diketahui atau patut diketahui bahwa barang atau jasa tersebut menggunakan merek terdaftar milik orang lain secara tanpa hak.

Di dalam Undang-Undang Merek No.14 Tahun 1997 perbuatan-perbuatan yang dilarang dalam ruang lingkup merek itu ada diatur di dalam Pasal 81-Pasal 84. Dalam hal ini perbuatanperbuatan yang dilarang dalam ruang lingkup tindak pidana merek yang diatur dalam UndangUndang No. 14 Tahun 1997 itu sama dengan yang diatur di dalam Undang-Undang No. 19 Tahun 1992, hanya saja perbedaannya terdapat di dalam Pasal 82 dimana di dalam undang-Undang No. 14 Tahun 1997 pada Pasal 82 telah disisipkan Pasal
82A dan Pasal 82B. Adapun perbuatan-perbuatan yang dilarang yang termasuk dalam ruang lingkup tindak pidana merek, antara lain:

Tiap perbuatan yang dilakukan oleh siapa pun juga dalam hal ini dengan sengaja dan tanpa hak menggunakan tanda yang sama pada keseluruhannya dengan indikasi geografis milik pihak lain untuk barang yang sama atau sejenis dengan barang yang terdaftar.

Tiap perbuatan yang dilakukan oleh siapa pun juga dalam hal ini dengan sengaja dan tanpa hak menggunakan tandayang sama pada pokoknya dengan indikasi geografis milik pihak lain untuk barang yang sama atau sejenis dengan barang yang terdaftar.

Tiap perbuatan yang dilakukan oleh siapa pun juga dalam hal ini dengan sengaja dantanpa hak menggunakan tanda yang dilindungi berdasarkan indikasi asal pada barang atau jasasehingga dapat memperdaya atau menyesatkan masyarakat mengenai asal barang atau jasa tersebut.

Menurut Undang-Undang No. 14 Tahun 1997 Jo Tahun 15 Tahun 2001 Tentang Merek Di dalam Undang-Undang Merek No.14 Tahun 1997 perbuatan-perbuatan yang dilarang dalamruang lingkup merek itu ada diatur di dalam Pasal 81Pasal 84. Dalam hal ini perbuatan-perbuatan yang dilarang dalam ruang lingkup tindak pidana merek yang diatur dalam Undang-Undang No. 14 Tahun 1997 itu sama dengan yang diatur di dalam Undang-Undang No. 19 Tahun 1992, hanya saja perbedaannya terdapat di dalam Pasal 82 dimana di dalam Undang-Undang No. 14 Tahun 1997 pada Pasal 82 telah disisipkan Pasal 82 A dan Pasal 82B. Adapun perbuatan-perbuatan yang dilarang yang termasuk dalam ruang lingkup tindak pidana merek, antara lain:

Tiap perbuatan yang dilakukan oleh siapa pun juga dalam hal ini dengan sengaja dan tanpa hak menggunakan tanda yang sama pada keseluruhannya dengan indikasi geografis milik pihak lain untuk barang yang sama atau sejenis dengan barang yang terdaftar.

Tiap perbuatan yang dilakukan oleh siapa pun juga dalam hal ini dengan sengaja dan tanpa hak menggunakan tanda yang sama pada pokoknya dengan indikasi geografis milik pihak lain untuk barang yang sama atau sejenis dengan barang yang terdaftar. 
Tiap perbuatan yang dilakukan oleh siapa pun juga dalam hal ini dengan sengaja dantanpa hak menggunakan tanda yang dilindungi berdasarkan indikasi asal pada barang atau jasa sehingga dapat memperdaya atau menyesatkan masyarakat mengenai asal barang atau jasa tersebut.

Sedangkan di dalam Undang-Undang No. 15 Tahun 2001 mengenai perbuatan-perbuatan yang dilarang didalam ruang lingkup merek terdapat perbedaan pengaturannya dimana di dalam Undang-Undang No. 14 Tahun 1997 perbuatan-perbuatan yang dilarang di dalam ruang lingkup merek ada di atur di dalam Pasal 81-Pasal 84 maka di dalam Undang-Undang No. 15 Tahun 2001 mengenai perbuatan-perbuatan yang dilarang dalam ruang lingkup merek ada diatur didalam Pasal 90-Pasal 94. Adapun perbuatanperbuatan yang dilarang yang termasuk dalam ruang lingkup tindak pidana merek, antara lain:

Tiap perbuatan yang dilakukan oleh siapa pun juga dalam hal ini dengan sengaja dan tanpa hak menggunakan merek yang sama pada keseluruhannya dengan merek terdaftar milik pihak lain untuk barang dan/atau jasa sejenis yang diproduksi dan/atau diperdagangkan.

Tiap perbuatan yang dilakukan oleh siapa pun juga dalam hal ini dengan sengaja dan tanpa hak menggunakan merek yang sama pada pokoknya dengan merek terdaftar milik pihak lain untuk barang dan/atau sejenis yang diproduksi dan/atau diperdagangkan.

Di dalam Pasal 92 Undang-Undang No. 15 Tahun 2001 tentang Merek ada terdapat 3 (tiga) ayat. Dimana pada ayat (1) perbuatan yang dilarang yang termasuk dalam ruang lingkup tindak pidana merek yaitu: Tiap perbuatan yang dilakukan oleh siapa pun juga dalam hal ini dengan sengaja dan tanpa hak menggunakan tanda yang sama pada keseluruhan dengan indikasi-geografis milik pihak lain untuk barang sama atau sejenis dengan barang yang terdaftar. Pada ayat (2) perbuatan yang dilarang yang termasuk dalam ruang lingkup tindak pidana merek yaitu: Tiap perbuatan yang dilakukan oleh siapa pun juga dalam hal ini dengan sengaja dan tanpa hak menggunakan tanda yang sama pada pokoknya dengan indikasi-geografis milik pihak lain untuk barang yang sama atau sejenis dengan barang yang terdaftar. Dan pada ayat (3) perbuatan yang dilarang yang termasuk dalam ruang lingkup tindak pidana merek yaitu: Terhadap pencantuman asal sebenarnya pada barang yang merupakan hasil pelanggaran ataupun pencantuman kata yang menunjukkan bahwa barang tersebut merupakan barang tiruan dari barang yang terdaftar dan dilindungi berdasarkan indikasi-geografis.

Tiap perbuatan yang dilakukan oleh siapa pun juga dalam hal ini dengan sengaja dan tanpa hak menggunakan tanda yang dilindungi berdasarkan indikasi-asal pada barang atau jasa sehingga dapat memperdaya atau menyesatkan masyarakat mengenai asal barang atau jasa tersebut.

Pada Pasal 94 ada terdapat 2 (dua) ayat, dimana pada ayat (1) mengenai perbuatan yang dilarang yang termasuk dalam ruang lingkup tindak pidana merek yaitu: Tiap perbuatan yang dilakukan oleh siapa pun juga dalam hal ini memperdagangkan barang dan/atau jasa yang diketahui atau patut diketahui bahwa barang dan/atau jasa tersebut merupakan hasil pelanggaran sebagaimana yang dimaksud pada pasal sebelumnya yaitu Pasal 90, Pasal 91, Pasal 92, dan Pasal 93. Dan pada ayat (2) mengenai perbuatan yang dilarang yang termasuk dalam tindak pidana merek disebutkan bahwa tindak pidana sebagaimana dimaksud pada ayat (1) adalah pelanggaran.

\section{Pertanggung Jawaban Bagi Pelaku Tindak Pidana Memperdagangkan Merek Palsu \\ Dari Segi Hukum Perdata}

Mengenai Peraturan Merek pada saat ini khususnya di negara Indonesia didasarkan pada Undang-Undang Nomor 15 Tahun 2001. Akibat hukum atas pendaftaran merek yang didaftarkan dengan itikad tidak baik sebagai akibat hukumnya adalah pembatalan merek yang didaftarkan yang dilakukan oleh Direktorat Jenderal. Selain didasarkan dengan itikad tidak baik masih ada juga alasan lain untuk mengajukan gugatan ke Pengadilan Niaga. Pemilik Merek terdaftar dapat mengajukan gugatan terhadap pihak lain yang secara tanpahak menggunakan Merek yang mempunyai persamaan pada pokoknya atau keseluruhannyauntuk barang atau jasa yang sejenis berupa:Gugatan ganti rugi, dan/atauPenghentian semua perbuatan yang berkaitan dengan penggunaan Merek tersebut. 
Gugatan atas pelanggaran Merek sebagaimana dimaksud dapat diajukan oleh penerima Lisensi Merek terdaftar baik secara sendiri maupun bersama-sama dengan pemilik Merek yang bersangkutan (Pasal 77 UU Nomor 15 Tahun 2001). Selama masih dalam pemeriksaan dan untuk mencegah kerugian yang lebih besar, atas permohonan pemilik Merek atau penerima Lisensi selaku penggugat, hakim dapat memerintahkan tergugat untuk menghentikan produksi, peredaran dan/atau perdagangan barang atau jasa yang menggunakan Merek tersebut secara tanpa hak. Dalam hal tergugat dituntut juga menyerahkan barang yang menggunakan Merek secara tanpa hak, hakim dapat memerintahkan bahwa penyerahan barang atau nilai barang tersebut dilaksanakan setelah putusan pengadilan mempunyai kekuatan hukum tetap.

Selain itu merek juga dapat dihapuskan jika merek yang didaftarkan tidak pernah diperdagangkan lagi selam 3 (tiga) tahun berturut-turut sejak tanggal pendaftaran atau pemakain terakhir. Penghapusan merek juga dapat dilakukan jika merek yang digunakan tidak sesuai dengan barang dan/atau jasa yang dimohonkan pendaftarannya. Mengenai penghapusan merek juga harus diumumkan dalam Berita Resmi Merek dan Daftar Umum Merek serta dimumkan agar para pemilik merek mengetahui dan masyarakat juga mengetahui. Keberatan terhadap keputusan atas penghapusan pendaftaran merek ini dapat diajukan pada Pengadilan Niaga.

\section{Dari Segi Hukum Pidana}

Dilihat dari segi hukum pidana jika pendaftaran merek didasarkan dengan itikad tidak baik tidak diatur dalam undang-undang. Dalam Undang-Undang Merek dikatakan bahwa atas pendaftaran merek yang didaftarkan atas dasar itikad tidak baik adalah dengan pembatalan hak atas merek tersebut. Namun dalam UndangUndang Nomor 15 Tahun 2001 tentang Merek.

Pasal 90 menyebutkan:

"Barang siapa dengan sengaja dan tanpa hak menggunakan merek yang sama pada keseluruhannya dengan merek yang terdaftar milik pihak lain untuk barang dan / atau jasa sejenis yang diproduksi dan/atau diperdagangkan, di pidana dengan pidana penjara paling lama 5 (lima) tahun dan/atau denda paling banyak Rp.1.000.000.000 (satu miliar rupiah)”.

Barang siapa dengan sengaja dan tanpa hak menggunakan merek yang sama Pasal 91 UU Nomor 15 Tahun 2001:

"Ada keseluruhannya dengan merek yang terdaftar milik pihak lain untuk barang dan / atau jasa sejenis yang diproduksi dan/atau diperdagangkan, di pidana dengan pidana penjara paling lama 4 (empat) tahun dan/atau denda paling banyak Rp. 800.000 .000 (delapan ratus juta rupiah)".

\section{Pasal 92:}

Barangsiapa dengan sengaja dan tanpa hak menggunakan tanda yang sama pada keseluruhan dengan indikasi-geografis milik pihak lain untuk barang yang sama atau sejenis dengan barang yang terdaftar, dipidana dengan pidana penjara paling lama 5 (lima) tahun dan/atau denda paling banyak Rp 1.000.000.000,00 (satu miliar rupiah).

Barangsiapa dengan sengaja dan tanpa hak menggunakan tanda yang sama pada pokoknya dengan indikasi-geografis milik pihak lain untuk barang yang sama atau sejenis dengan barang yang terdaftar, dipidana dengan pidana penjara paling lama 4 (empat) tahun dan/atau denda paling banyak Rp 800.000.000,00 (delapan ratus juta rupiah).

Terhadap pencantuman asal sebenarnya pada barang yang merupakan hasil pelanggaran ataupun pencantuman kata yang menunjukkan bahwa barang tersebut merupakan tiruan dari barang yang terdaftar dan dilindungi berdasarkan indikasi-geografis, diberlakukan ketentuan sebagaimana dimaksud pada ayat (1) dan ayat (2).

Pasal 93:

Barangsiapa dengan sengaja dan tanpa hak menggunakan tanda yang dilindungi berdasarkan indikasi-asal pada barang atau jasa sehingga dapat memperdaya atau menyesatkan masyarakat mengenai asal barang atau asal jasa tersebut, dipidana dengan pidana penjara paling lama 4 (empat) tahun dan/atau denda paling banyak Rp 800.000.000,00 (delapan ratus juta rupiah).

Pasal 94:

Barangsiapa memperdagangkan barang dan/atau jasa yang diketahui atau patut diketahui bahwa barang dan/atau jasa tersebut merupakan hasil pelanggaran sebagaimana dimaksud dalam Pasal 90, Pasal 91, Pasal 92, dan Pasal 93 dipidana dengan pidana kurungan paling lama 1 (satu) 
tahun atau denda paling banyak Rp 200.000.000,00 (dua ratus juta rupiah).

Tindak pidana pada Pasal 94 merupakan tindak pidana pelanggaran sedangkan tindak pidana sebagaimana dimaksud dalam Pasal 90, Pasal 91, Pasal 92, dan Pasal 93, merupakan delik aduan.

\section{Dari Segi Hukum Administrasi Negara}

Dari segi Administrasi merek diatur dalam Undang-Undang Nomor 15 Tahun 2001 dilaksanakan oleh Direktorat Jenderal. Direktorat Jenderal menyelenggarakan sistem jaringan dokumentasi dan informasi merek yang bersifat nasional, yang mampu menyediakan informasi tentang merek seluas mungkin kepada masyarakat.

Untuk setiap pengajuan permohonan atau permohonan perpanjangan merek, permohonan petikan Daftar Umum Merek, pencatatan pengalihan hak, perubahan nama dan/atau lisensi atau alamat pemiliki merek terdaftar, pencatatan perjanjian lisensi, keberatan terhadap permohonan, permohonan banding serta lainlainnya yang ditentukan dalam undang-undang ini wajib dikenakan biaya yang besarnya ditetapkan dala Peraturan Pemerintah.

Dalam hal pendaftaran merek didasarkan dengan itikad tidak baik dan ada pihak yang merasa dirugikan dan keberatan pendaftaran dan penerbitan Sertifikat tersebut maka akan diumumkan dan akibat lain yang diperoleh adalah tentang tidak digunakan lagi merek tersebut oleh masyarakat karena sedang dalam perkara kepemilikan hak atas merek tersebut.

Upaya Penanggulangan Terhadap Tindak Pidana Memperdagangkan Merek Palsu

Upaya Penanggulangan Penal (Penal Policy)

Penanggulangan kejahatan melalui

kebijakan pidana (penal policy) merupakan tindakan pemidanaan terhadap narapidana. Pemidanaan ini memiliki tujuan yang berbedabeda sesuai dengan teorinya masih-masing. Pembabakan tentang tujuan pemidanaan ini dapat diuraikan berdasarkan tujuan retributif, deterrence, treatment, dan social defence (Mulyadi, 2008: 68).

Teori Retributif dalam tujuan pemidanaan disandarkan pada alasan bahwa pemidanaan merupakan "morally justifed" (pembenaran secara moral) karena pelaku kejahatan dapat dikatakan layak untuk menerimanya atas kejahatannya. Asumsi yang penting terhadap pembenaran untuk sebagai respon terhadap suatu kejahatan karena pelaku kejahatan telah melakukan pelanggaran terhadap norma moral tertentu yang mendasari aturan yang dilakukannya secara sengaja dan sadar dan hal ini merupakan bentuk dari tanggungjawab moral dan kesalahan si pelaku.

Teori retributif ini menyatakan bahwa pemidanaan adalah sebagai sarana pembalasan atas kejahatan yang telah dilakukan seseorang. Karena kejahatan dipandang sebagai perbuatan yang amoral di tengah-tengah masyarakat, oleh karena itu pelaku kejahatan harus menerima pembalasan dari perbuatan yang telah dilakukannya dengan dijatuhi pidana.

\section{Teori Deterrence}

Menurut teori ini, tujuan pemidanaan adalah sebagai sarana penjatuhan terhadap pelaku tindak pidana, akan tetapi penjatuhan ini hanya sebatas ancaman agar orang merasa takut dan menahan diri untuk melakukan kejahatan di tengah-tengah masyarakat.(Fatic, 1995: 9)

\section{Teori Treatment}

Teori Treatment ini mengemukakan bahwa tujuan pemidanaan ini sangatlah pantas diarahkan kepada pelaku kejahatan, bukan pada perbuatan kejahatan yang telah dilakukannya. Karena tujuan pemidanaan yang dimaksudkan pada teori ini adalah memberikan tindakan perawatan (treatment) dan perbaikan (rehabilitation) kepada para pelaku kejahatan sebagai pengganti dari. Dengan cara ini diharapkan apabila pelaku kejahatan tersebut telah menjalani masa perawatan dan perbaikan, maka diharapkan dapat kembali diterima ditengah-tengah masyarakat dan tidak mengulangi perbuatannya lagi.

\section{Teori Social Defence}

Teori ini merupakan aliran pemidanaan yang berkembang setelah Perang Dunia Ke II dengan tokoh terkenalnya adalah Fillipo Gramatica, pada tahun 1945 mendirikan Pusat Studi Perlindungan Masyarakat. Dalam perkembangan selanjutnya, pandangan social defence ini terpecah menjadi dua aliran, yaitu aliran yang radikal (ekstrim) dan aliran yang moderat (reformis). (Fatic, 1995: 88)

Pandangan yang radikal ini dipelopori dan dipertahankan oleh F. Gramatica, yang salah satu 
tulisannya berjudul "The fight against punishment" (La Lotta Contra La Pena). Gramatika menggantikan pidana yang ada sekarang. Tujuan utama dari perlindungan sosial adalah mengintegrasikan individu ke dalam tertib sosial dan bukan pemidanaan terhadap perbuatannya. (Muladi dan Arief, 2002 : 35)

Pandangan moderat dipertahankan oleh Marcacel (Prancis) yang menamakan alirannya sebagai "Defence Sociale Nouvelle" atau "New Social Defence" atau "Perlindungan Social Baru". Menurut Marc Ancel, tiap masyarakat mensyarakatkan adanya tertib sosial, yaitu seperangkat peraturan-peraturan yang tidak hanya sesuai dengan kebutuhan untuk kehidupan bersama, tetapi sesuai dengan aspirasi warga masyarakat pada umumnya. Oleh karena itu, peranan yang besar dari pidana merupakan kebutuhan yang tidak dapat dielekkan bagi suatu sistem. Beberapa konsep pandangan moderat adalah sebagai berikut:

1. Pandangan moderat bertujuan mengintegrasikan ide-ide atau konsepsikosepsi perlindungan masyarakat ke dalam konsepsi baru pidana.

2. Perlindungan individu dan masyarakat tergantung pada perumusan yang tepat mengenai pidana, dan ini tidak kurang pentingnya dari kehidupan masyarakat itu sendiri.

3. Dalam menggunakan sistem pidana, aliran ini menolak penggunaan fiksi-fiksi dan teknikstekniks yuridis yang terlepasdari kenyataan sosial. Ini merupakan reaksi terhadap legisme dari aliran klasik.

4. Dalam rangka upaya menanggulangi tindak pidana di bidang merek ada beberapa upaya yang harus dilakukan, antara lain: (http://www.dgip.go.id/ebhtml/hki/filecontent.p hp?fid=10980, Diakses tanggal 2 Maret 2010 Pukul: 10.00.00 Wib)

5. Menyediakan sistem perlindungan di bidang merek dengan standar tinggi.

6. Mempromosikan kegiatan-kegiatan yang mendorong pertumbuhan di bidang merek.

7. Mempromosikan eksploitasi kekayaan intelektual berpotensi komersial.

8. Meningkatkan kemampuan pengelolaan kekayaan intelektual.

9. Pengembangan infrastruktur transaksi kekayaan intelektual.
10. Meningkatkan perlindungan kekayaan intelektual untuk kepentingan nasional.

11. Meningkatkan kemampuan Sumber Daya Manusia (SDM) dan kepedulian masyarakat dalam bidang kekayaan intelektual.

12. Mempromosikan investasi asing dan ahli teknologi.

Selain itu ada juga beberapa upaya penanggulangan di dalam tindak pidana merek, (http://www.dgip.go.id/ebhtml/hki/filecontent.php? fid=10980, Diakses tanggal 2 Maret 2010 Pukul: 10.00.00 Wib yaitu:

Pencegahan dan penegakan hukum di bidang merek.

Sosialisasi serta mengadakan dan meningkatkan kerjasama secara bilateral, regional maupun multilateral dalam rangka penanggulangan pelanggaran hak kekayaan intelektual ( $\mathrm{HKI})$.

Pemerintah juga memberikan peranan dalam melakukan upaya penanggulangan dalam tindak pidana yaitu dengan membentuk Tim Nasional (Timnas) Penanggulangan Pelanggaran HKI (PPHKI), dimana tugas dari Timnas PPHKI, antara

lain (http://www.dgip.go.id/ebhtml/hki/filecontent.php? fid=10980, Diakses tanggal 2 Maret 2010 Pukul: 10.00.00 Wib) :

1. Melakukan inventarisasi dan evaluasi data penanganan perkara pelanggaran $\mathrm{HKl}$, baik di bidang pidana maupun perdata.

2. Pemberdayaan PPNS HKI dalam menangani tindak pidana $\mathrm{HKI}$.

3. Meningkatkan koordinasi dengan instansiterkait khususnya dengan Direktorat Jenderal Bea dan Cukai dalam menangkal produk-produk yang diduga merupakan pelanggaran $\mathrm{HKI}$.

4. Melakukan himbauan kepada instansi Pemerintah dan BUMN agar menggunakan produk barang/jasa yang bermerek asli.

Adapun yang menjadi kendala di dalam melakukan upaya penanggulangan di bidang merek adalah (http://www.dgip.go.id/ebhtml/hki/filecontent.php? fid=10980, Diakses tanggal 2 Maret 2010 Pukul: 10.00.00 Wib).

Hampir seluruh pelaku usaha UMKM (Usaha Mikro Kecil Menengah) belum memahami pentingnya melindungi HKI.hal ini terlihat ketika UMKM akan melakukan ekspor produknya. 
Mereka menganggap apabila telah diberi perlindungan $\mathrm{HKl}$ di lndonesia kepentingan perlindungan HKI-nyatelah selesai. Padahal pada tujuan Negara ekspor tidak dimintakan perlindungan. Pelaksanaan pameran UMKM di luar negeri juga tidak melibatkan kepentingan perlindungan $\mathrm{HKl}$ terlebih dahulu terutama di negara yang melangsungkan pameran produk UMKM di luar negeri.

Berkembangnya pemasaran produk UMKM melalui media internet juga masih belum melibatkan kepentingan perlindungan $\mathrm{HKI}$ khususnya di luar negeri. Inovasi di bidang HKI menjadikanpelaku usaha berindak sebagai trend setter (pendahulu/pembaharu produksi dan pasar). Meluasnya penyebaran usaha kreatif rentan terhadap salah tafsir terhadap pandangan system HKI. Hal ini karena terbentuknya pemahaman mengikuti nilai kebanggaan apabila keberhasilannya ditiru oleh pihak lain dalam lingkungan masyarakat usaha sejenis sehingga sukar membuktikan adanya komitmen meghormati perlindungan $\mathrm{HKl}$.

\section{Upaya Penanggulangan Non Penal (Non Penal Policy)}

Upaya penanggulangan kejahatan melalui metode ini lebih bersifat tindakan pencegahan saja sebelum terjadinya tindakan kejahatan. Cara ini dilakukan untuk mengetahui atau mencari tahu apa saja penyebab-penyebab terjadinya kejahatan itu. Sehingga dengan cara pencegahan ini, diharapkan kejahatan yang dilakukan oleh para pelaku tindak pidana merek tidak dapat terjadi ataupun tidak dapat berkembang secara pesat di tengah masyarakat.

Upaya ini merupakan upaya yang paling penting, sebab apabila upaya ini dijalankan dengan baik maka tindak pidana yang dilakukan oleh pelaku tindak pidana merek tidak akan pernah terjadi. Upaya ini juga merupakan upaya yang strategis dan harus diintensifkan, sebab upaya ini dapat menekan ataupun meminimalisir terjadinya tindak pidana di tengah-tengah masyarakat.

Faktor utama yang menyebabkan seseorang melakukan kejahatan adalah karenakondisi sosial/faktor ekonomi. Kondisi sosial yang ditenggarai sebagai faktor penyebab timbulnya masalah kejahatan merupakan masalah yang sulit dipecahkan apabila hanya mengandalkan pendekatan penal semata. Oleh karena itulah, pemecahan masalah diatas harus didukung oleh pendekatan non-penal berupa kebijakan sosial dan pencegahan kejahatan berbasiskan masyarakat.

\section{SIMPULAN}

Sesuai dengan Undang-Undang No. 15 Tahun 2001 tentang Merek bentuk pertanggung jawaban bagi pelaku tindak pidana yang memperdagangkan merek palsu adalah dapat dilihat dari segi hukum perdata dengan meminta ganti rugi, dan penghentian menggunakan merek. Dalam hukum pidana dapat berupa hukuman penjara sesuai dengan ketentuan yang berlaku dan juga denda serta dapata sanksi administrasi.

Upaya penanggulangan mencegah perdagangan merek jam palsu adalah: Menyediakan sistem perlindungan di bidang merek dengan standar tinggi. Mempromosikan kegiatan-kegiatan yang mendorong pertumbuhan di bidang merek. Mempromosikan eksploitasi kekayaan intelektual berpotensi komersial. Meningkatkan kemampuan pengelolaan kekayaan intelektual. Pengembangan infrastruktur transaksi kekayaan intelektual. Meningkatkan perlindungan kekayaan intelektual untuk kepentingan nasional. Meningkatkan kemampuan Sumber Daya Manusia (SDM) dan kepedulian masyarakat dalam bidang kekayaan intelektual. Mempromosikan investasi asing dan ahli teknologi.

\section{DAFTAR PUSTAKA}

Jumroh, A., 2012. "Hak Kekayaan Intelektual", Medan Area University Press.

Fatic, A., 1995. "Punishment and Retrorative Crime - Handling", USA: Avebury Ashagate Publishing limited.

Hamzah, A., 2003. "Peranan Hukum dan Peradilan". Bina Aksara.jakarta. 2008, “Asas-Asas Hukum Pidana”, PT. Rineka Cipta, Jakarta.

Waluyo, B., 2008, “Pidana dan Pemidanaan”, Sinar Grafika, Jakarta.

Budi, S., 2009. "Pengantar HKI Dan Audit HKI Untuk Perusahaan”, Penerbit Pustaka Magister, Semarang.

Harsono, A., 1990. "Hak Milik Perindustrian", Akademika Pressindo, Jakarta. 
lswi, H, 2010. "Prosedur Mengurus HAKI yang Benar”, Penerbit Pustaka Yustisia, Yogyakarta.

Kanter dan Sianturi. 2002. "Asas-Asas Hukum Pidana Di Indonesia dan Penerapannya". Storia Grafika. Jakarta.

Mulyadi, M., 2008. "Pendekatan Integral Penal Policy dan Non-Penal Policy dalam Penanggulangan Kejahatan Kekerasan", Medan: Pustaka Bangsa Press.

Muladi dan Barda N.A., 2002. "Teori-Teori dan Kebijakan Pidana”, Alumni. Bandung.

Moeljatno, 2002, “Asas-Asas Humum Pidana”, PT. Rineka Cipta, Jakarta.

Moeljatna, 2007 “Asas-Asas Hukum Pidana”, Bina Aksara. Jakarta.

Ali, M., 2004. “Kamus Lengkap Bahasa Indonesia Moderen”. Penerbit Pustaka Amani, Jakarta.

Ok, S., 2010. “Aspek Hukum Hak Kekayaan Intelektual ", Raja Grafindo Persada, Jakarta.

Purwo, S., 2012. "Pengertian Pokok-Pokok Hukum Dagang Indonesia”,Djambatan, Jakarta.

Saleh. R., 2002. "Pikiran-pikiran Tentang Pertanggungjawaban Pidana”. Ghalia Indonesia. Jakarta.

Soekanto, S., 2004. “Pengantar Penelitian Hukum”, ul-Press, Jakarta.

Sukardono, 1983. "Hukum Dagang Indonesia”, Dian Rakyat, Jakarta.

Suryatin, 1980. “Hukum Dagang I dan II", Pradnya Paramita, Jakarta.

Suryodiningrat, 1981. “Aneka Milik Perindustrian”, Tarsito, Bandung.

Tim, L., 200o. “Hak Kekayaan Intelektual Suatu Pengantar", Alumni, Bandung.

Kitab Undang-Undang Hukum Pidana

Kitab Undang-Undang Hukum Acara Pidana

Undang-Undang No. 15 Tahun 2001 Tentang Merek

\section{Internet}

http://www.dgip.go.id/ebhtml/hki/filecontent.php?f id=10980, Diakses tanggal 2 Maret 2010 Pukul: 10.00.00 Wib.

http://syarifblackdolphin.wordpress.com/2012/01/11/ pertanggungjawaban-pidana/ Diakses pada tanggal 29 Nopember 2010 Pukul 10.15.20 Wib
Usman, R., 2003. "Hukum Hak Atas Kekayaan Intelektual: Perlindungan dan Dimensi Hukumnya di Indonesia", Alumni, Bandung. Utomo, T.S., 2010. "Hak Kekayaan Intelektual (HKI) di Era Global: Sebuah Kajian Kontemporer", Graha llmu, Yogyakarta. 